\title{
The Enigma of the Gajda Affair in Czechoslovak Politics in 1926
}

While historians have studied Pilsudski's coup d'état in Poland extensively, ${ }^{1}$ histories of interwar Eastern Europe either totally ignore or make only guarded references to an alleged attempted coup in Czechoslovakia in the same year under the aegis of the prominent general and former Russian legionary, Radola Gajda (1892-1948). In 1926, Gajda, the acting chief of staff of the Czechoslovak Army, was removed from his post to be tried and convicted for having committed several treasonable offenses against the Czechoslovak state. Historians agree that Gajda harbored Fascist political sympathies-as after his dismissal from the army, he became the leader of the "National Fascist Community" (Národni obec fašistická or NOF), the small Czech Fascist movement-but no one has written in detail about Gajda's career in the army before 1926. Two older accounts of Czechoslovak politics by Ferdinand Peroutka and Harry Klepetár briefly discuss the sensational scandal surrounding Gajda, ${ }^{2}$ and several Communist historians have asserted that Gajda reached an agreement with the Slovak leader Vojtech (Béla) Tuka to carry out a coup against the government during the 1926 Sokol gymnastic congress. ${ }^{3}$ However, no detailed documentation of hard plotting by Gajda has ever been produced. One is left, therefore, with the question of whether Gajda really attempted to carry out a coup in 1926, or whether the "Gajda affair," as it was known in Czechoslovakia, has been obscured by popular misconceptions about Gajda and by the intrigues accompanying the 1966).

1. On Pilsudski's coup, see Joseph Rothschild, Pilsudski's Coup d'Etat (New York,

2. Ferdinand Peroutka, Budováni státu [The Building of the State], vol. 5 (Prague, 1938), pp. 2818-25 (hereafter cited as Peroutka); Harry Klepetáŕ, Seit 1918 (Moravská Ostrava, 1937), pp. 238-42 (hereafter cited as Klepetár).

3. Vèra Olivová, The Doomed Democracy (London, 1972), p. 159; Alena Gajanová, CSR a stredoevropska politika velmoci 1918-1938 [The Cacchoslovak Republic and the Central European Policy of the Great Powers, 1918-1938] (Prague, 1967), p. 216; Alena Gajanová, Dvojí tvár [Trvo-faced] (Prague, 1962), pp. 42-43; Zdeněk Solle and Alena Gajanová, Po stopè dějin [On the Trail of History] (Prague, 1969), pp. 260-61.

A version of this article was first delivered to a meeting of the Czechoslovak Society of Arts and Sciences in November 1974. The writer is grateful to F. Gregory Campbell, Jr., Yeshayahu Jelinek, Vladimir Socor, and Stanley Winters for suggestions relating to this subject. 
Czechoslovak coalition parties' political negotiations in $1926 .{ }^{4}$ While one cannot explain all the facets of the Gajda affair without access to Czechoslovak military and political archives (which are closed to foreign researchers), American, British, and French diplomatic reports used in conjunction with published Czechoslovak sources may clarify what happened to Gajda and his supporters, as well as the reason for the curious lack of documentation about Gajda's activities in writings by contemporary Czechoslovak historians. Indeed, the Gajda affair involved not only Czechoslovak political figures, such as President Tomáš Masaryk and Foreign Minister Edvard Beneš, but also foreign diplomats, including the Soviet trade representative to Czechoslovakia, Vladimir Antonov-Ovseenko.

Next to General Jan Syrový (1888-1971) the hero of the battle of Zborov in July $1917,{ }^{5}$ Gajda was the most prominent former Russian legionary in the Czechoslovak Army. Gajda was a Pan-Slav Czech and anti-German chauvinist. He was born in 1892 at the Austrian naval base of Cattaro (Kotor). He learned Serbo-Croatian as a child and Slavicized his original German name, Rudolf Geidl, to Radola Gajda before the First World War. A man of limited education, he began the war as a druggist in the sanitary corps of the Austro-Hungarian Army on the Serbian front. After deserting to the Montenegrins in 1915, he stayed with them until the occupation of Montenegro, when he made his way to Russia. In Russia, following a series of adventures (which are described with exaggeration in his entertaining memoirs), ${ }^{8}$ Gajda came to serve as Admiral Alexander V. Kolchak's chief of staff and later as the commander of one of the Czechoslovak armies in Siberia. Though unsophisticated and vain, Gajda possessed a natural intelligence and colorful personality that enabled him to rise rapidly in the Siberian legions. General Charles Mittelhauser, the French general who was chief of the Czechoslovak General Staff from 1921 to 1925, characterized Gajda as possessing all the advantages and disadvantages of a condottiere. ${ }^{7}$

Gajda's restless and cantankerous personality led him into repeated conflicts with his fellow officers and superiors both in Siberia and in postwar

4. On the background of Czechoslovak politics, see Victor S. Mamatey, "The Development of Czechoslovak Democracy, 1920-1938," in Victor S. Mamatey and Radomír Luža, eds., $A$ History of the Caechoslovak Republic, 1918-1948 (Princeton, 1973), pp. 99142.

5. Jan Syrový was the chief of staff of the Czechoslovak Army from 1926 to 1933, inspector-general from 1934 to 1938 , and prime minister and minister of national defense from late September 1938 to the German occupation in March 1939. In 1947 he was condemned to twenty years' imprisonment for collaboration with the Germans.

6. Radola Gajda, Moje pamèti [My Memoirs] (Karlín, 1920).

7. Le Général Mittelhauser à M. le Ministre de la Guerre, le 30 mars 1923, no. 220/cab. Records of the Service Historique de l'Armée, Section Contemporaine (hereafter cited as SHA:SC), Carton 2 on Czechoslovakia (hereafter cited as T-2), Vincennes, France. For a good character sketch of Gajda, see Peroutka, vol. 5, pp. 2815-17. 
Czechoslovakia. On his return home in 1920, Gajda proved especially troublesome to the Czechoslovak government and to the French military mission to Czechoslovakia, which was in charge of the army's organization and instruction. Gajda, who was twenty-eight at the time, wanted to assume a key position in the new army; but the authorities decided to remove him from Czechoslovak military affairs by sending him to France to study at the Ecole de Guerre. ${ }^{8}$ (This course of action was not recommended for the equally prominent but more docile Jan Syrový, who was given appointments such as the command of the Prague Military District and the post of deputy chief of staff.) After finishing his studies in France, Gajda was again refused an influential post in the army. Instead, he was given the important command of the Košice district in eastern Slovakia, which was purposefully chosen for its distance from the army's central administration. Though Mittelhauser hoped that Gajda would keep out of trouble, Gajda agitated for a promotion and flirted with right-wing politicians, including the Slovak leader Father Andrej Hlinka and the leader of the conservative National Democratic Party and first Czechoslovak prime minister, Karel Kramár (1860-1937). ${ }^{9}$

In many countries, Gajda's notorious political activities and insubordination could have easily provided just cause for removal from the army. Gajda constantly tried to impress his personal views on the army high command, and on one occasion he even drew up a report on how he felt the army should be reformed and submitted it directly to President Masaryk without informing his superior, General Mittelhauser. Though Mittelhauser was justifiably infuriated at Gajda's absurd proposals (which called for the placing of many of Czechoslovakia's infantry divisions on a constant war footing), there was nothing that he could do to discipline Gajda because of the latter's influence among the Russian legionaries. ${ }^{10}$ Czechoslovakia's legionaries, especially those who had served in Russia, were popular heroes in Czechoslovak society and politics, ${ }^{11}$ and Gajda was one of the most important legionary leaders. None-

8. Gajda admitted this to an American officer who was studying in France at the time. Letter of Colonel Arthur Budd to A.C. of S., G-2, March 17, 1939. Records of the United States War Department (hereafter cited as USWD), National Archives of the United States, Washington, D.C., 2494-214.

9. H. M. Consul, Bratislava, to Sir George Clerk, June 2, 1926, no. 14, enclosure in Sir George Clerk to Sir Austin Chamberlain, June 8, 1926, no. 187. Records of the British Foreign Office, Series 371 (hereafter cited as F.O.), Public Record Office, London, England, C 6737/83/12; Josef Svatopluk Machar, Pèt rokì v kasámách [Five Years in the Barracks] (Prague, 1927), pp. 373-74 (hereafter cited as Machar); Peroutka, vol. 5, p. 2818.

10. Le Général Mittelhauser à $M$. le Ministre de la Guerre, le 30 mars 1923, no. $220 / \mathrm{cab}$., SHA:SC, T-2.

11. There are numerous studies of the legionaries; for a recent study, see Gerburg Thunig-Nittner, Die tschechoslowakische Legion in Russland (Wiesbaden, 1970) (hereafter cited as Thunig-Nittner). 
theless, because of Gajda's activities, President Masaryk decided to bring him back to Prague, where he could be kept under the watchful eyes of more reliable officers. ${ }^{12}$ In November 1924, Gajda was appointed first deputy chief of staff, a position with an impressive title but with limited practical power. Gajda was still subordinate to Mittelhauser and his assistant chief of staff, while another French officer, General Louis Eugène Faucher, served as second deputy chief of staff.

After his return from Slovakia, Gajda continued his political activities, and he became particularly attracted to the model of Italian fascism. ${ }^{13}$ In the fall of 1925, he helped found a right-wing organization of Czechoslovak legionaries, the Nezávislá jednota legionárù (the Independent Union of Legionaries), in opposition to the influential Československá obec legionár̆ská (the Czechoslovak Legionary Community), which followed Masaryk's leadership. ${ }^{14}$ Gajda also supported Czech Fascist organizations such as the Národni hnuti (the National Movement), which merged in early 1926 into the Národni obec fašistická. As a military officer, Gajda could not hold office in the NOF, ${ }^{15}$ but, much to the dismay of the supporters of Masaryk and Beneš in the Prague Hrad (Castle), he endorsed NOF activities, as did Kramár, right-wing National Socialist and newspaper editor Jiři Střibrný (18801955), and the Czech poet Viktor Dyk (1877-1931).

Throughout 1925 Gajda was a nuisance to Masaryk, but Gajda was ousted from the army in the "Gajda affair" scandal only in the wake of two complex series of events in Czechoslovak political and military life. First of all, serious disputes broke out within the closely-knit coalition which formed Czechoslovakia's multiparty government. In the 1925 general elections, several coalition partners were defeated. Following the elections, a new cabinet was formed under the Agrarian politician Antonín Švehla (1873-1933) in which Střibrný replaced a prominent Agrarian, František Udržal (1866-1938), as minister of national defense. ${ }^{16}$ This cabinet fell in March 1926 and was re-

12. Comment of Masaryk to the British minister, Sir George Clerk to Sir A. Chamberlain, October 6, 1926, no. 288, F.O. 10842/83/12. See also Machar, pp. 373-78.

13. See Tomáš Pasák, " $K$ promblematice NOF $v$ letech hospodářské krize na počátku trricátých let" [On the Problems of the NOF in the Years of the Economic Crisis in the Beginning of the 1930s], Sbornik historicky, 13 (1965), p. 96 (hereafter cited as Pasák).

14. Thunig-Nittner, pp. 232-35.

15. Alena Gajanová, "Ceský fašismus" [Czech Fascism] in Prispevky $k$ dejinaim fasizmu $v$ Ceskoslovensku a Mad'arsku [Contributions to the History of Fascism in Czechoslovakia and Hungary] (Bratislava, 1969), p. 69.

16. See Erik Polák, "K otázce rozpadu všenárodní koalice a nastolení vlády mezinárodni buržoazie $v$ československu $v$ letech 1925-1926" [On the Question of the Disintegration of the Government of the Multi-National Coalition and the Installation of the Government of the International Bourgeoisie in Czechoslovakia in the Years 19251926], Ceskoslovensky ćasopis historický, 9, no. 1 (1961): 17-41. On the 1926 crisis, see Dušan Uhlír, "Republikánská strana lidu zemědělskẻho a malorolnického ve vládě panské 
placed by a nonpolitical cabinet of experts under a bureaucrat, Jan .Cerný (1874-1959), as was permitted by the Czechoslovak constitution. Kramár's National Democrats and the Stríbrny wing of the National Socialists tried to oust Beneš as foreign minister, but Masaryk refused to appoint a new cabinet without Beneš. Beneš finally resigned his membership in the National Socialist Party in order to remain in the Cerny cabinet. ${ }^{17}$

Instead of calming the Czechoslovak political scene, the Cerny' cabinet provided the occasion for exacerbated political rivalries and scandals reminiscent of the bickerings in the Austrian parliament before 1914. Most of the political debate in 1926 centered around disagreements between the conservative nationalistic factions of Střibrný and Kramár on the one hand, and Beneš, Masaryk, and their Socialist supporters on the other. Within the National Socialist Party, Střibrný had a bitter feud with the party's leader, Václav Klofáč, who had close ties to Masaryk. Initially, Gajda was only indirectly involved with these political disputes, but through his relationship with Kramár and Stríbrný, he became the object of increasing controversy. ${ }^{18}$

The political clisputes of 1925 and 1926 were accompanied by a second series of events within the army which led to Gajda's appointment as acting chief of staff. Following a longstanding agreement with France, on January 1, 1926, Syrový replaced Mittelhauser as chief of staff. A native Czechoslovak officer now took over the post hitherto held by the chiefs of the French military mission. In February, Mittelhauser left for France leaving Faucher in charge of the mission. Gajda and Faucher remained as deputy chiefs of staff, and the post of assistant chief of staff, which had been created to prepare Syrový for his promotion, was abolished. When the Cerny cabinet was formed in March, Faucher saw an opportunity for instituting badly needed reforms in the Ministry of National Defense, which had hitherto been relatively independent of the control of the French military mission. Faucher made an agreement with the outgoing minister, Stribrný, to appoint Syrový to the ministry

koalice" [The Republican Party of the Agrarian and Small Peasant People in the Cabinet of the Gentlemen's Coalition], Ceskoslovenský časopis historický, 18, no. 2-3 (1970): 195-236.

17. Cf. the comments about Beneš in the report enclosed in Le Général Faucher à M. le Ministre de la Guerre, le 16 juillet 1926, no. 562/cab., SHA:SC, Carton 3 on Czechoslovakia (hereafter cited as $T-3$ ).

18. The French minister observed that the formation of the cabinet of experts was accompanied by a degeneration of the political struggle into a free-for-all of personal attacks: Gajda calumniated his detractors, Klofác produced a medical certificate in parliament alleging the partial paralysis and nervous breakdown of Stŕíbrný, Beneš published the details of Střibrny's personal finances, and Masaryk imprudently attacked the National Democrats in a newspaper interview. See M. Couget (Ministre de France à Prague) à M. Briand, le 13 septembre 1926, Records of the French Foreign Ministry (hereafter cited as MAE), Quai d'Orsay, Paris, European series, Czechoslovakia, no. 9 (hereafter cited as T-9). 
as a nonpolitical expert to institute reforms under French guidance. ${ }^{19}$ When Syrový was appointed to the cabinet on March 19, Gajda became chief of staff on a temporary (per interim ) basis until a new political cabinet could be formed.

Gajda's temporary promotion aroused fears among center and left-wing politicians that he might use his position to further political ambitions. In early March, the Social Democratic paper, Právo lidu, stated that, on trips to Brno in connection with his duties as a member of the governing board of Zbrojovka (the Czechoslovak Armament Works), Gajda helped organize a chapter of the Nezávislá jednota legionári April he visited Slovakia to inspect army units, and an officer confidant of the German consul in Bratislava told the consul that Gajda was holding closed meetings of legionaries in order to ascertain the extent of his legionary support and to give new impetus to his following. The officer asserted that Gajda was interested in strengthening the right wing in Czechoslovak politics but not in carrying out an actual coup. ${ }^{21}$

Despite these activities, Gajda might have ridden out his appointment without serious incident had it not been for the Pilsudski coup in Poland, which was carried out in the aftermath of the fall of the Skrzyniski government on May 5. Gajda had been attacked in the Czechoslovak parliament as early as April 22, when a Czech senator denounced him, ${ }^{22}$ but the Pilsudski coup provoked a strong reaction in Czechoslovakia, crystallizing sentiment for and against Gajda. In early 1926, Czechoslovak politics had been tumultuous not only because of the instability of the government coalition but also because of incidents between right-wing Czechs and Germans. The anti-Semitic Národni hnuti favored by Kramár was a particular source of unrest. ${ }^{23}$ Sudeten German politicians became increasingly upset by the chauvinism of Czechs like Kramár ; and according to the American minister to Prague, rumors began to spread in German areas of Bohemia that Gajda might attempt a Fascist coup. ${ }^{24}$ On May 13, when the Pilsudski coup was still in progress, a close ally of Benes, the Social Democrat Rudolf Bechyně, attacked Gajda in the Social Democratic paper Nová swoboda (New Freedom). Bechynè linked Gajda to the National Democrats and accused right-wing groups of searching for a "general" to lead a coup. Bechyně's diatribe prompted a furious debate about Gajda in the

19. Chef Mission à Guerre, le 19 mars 1926, SHA:SC, T-3.

20. Koch an Auswärtiges Amt, den 8. März 1926, Microcopy T-120 (Records of the German Foreign Ministry), roll 447, U.S. National Archives, Washington, D.C.

21. Reinebeck an Auswärtiges Amt, den 30. April 1926, ibid.

22. Klepetár, p. 240 , quotes a short excerpt from the debate. T-3.

23. "Le fascisme tchéchoslovaque et l'armée," le 23 mai 1926, no. 2831/cab., SHA:SC,

24. Einstein to secretary of state, May 28, 1926, Records of the U.S. Department of State (hereafter cited as USSD), 860f.00f/1. 
Czechoslovak press. ${ }^{25}$ The forthcoming Sokol congress (a gala display of Czech gymnastics held every six years), scheduled for July 4-6, provided the incentive for further rumor that Gajda might use the Sokol organization, which was known for its nationalism, to venture a "march on Rome." Czech Fascists openly touted the slogan: "Co Cech, to Sokol, co Sokol, to fašista" ("Every Czech is a Sokol, every Sokol is a Fascist"). ${ }^{26}$

Although the attacks on Gajda intensified, Gajda himself remained outwardly passive. As an officer, he was forbidden to defend himself publicly, and the Ministry of National Defense released a statement denying that Gajda was involved in any wrongdoing. ${ }^{27}$ Nonetheless, both left- and right-wing papers continued to speculate about Gajda, and sharp debates about him raged in the Parliament. Masaryk, Beneš, Klofáč, and the Social Democratic Party leaders worked assiduously for Gajda's ouster. In 1943, Beneš recalled that Masaryk even tried to buy off Gajda by sending him money. Gajda supposedly pocketed the money but did not retire as Masaryk had suggested. ${ }^{28}$ Finally, on July 2, Masaryk removed Gajda from his post, sent him on leave, and had him investigated for possible misconduct. ${ }^{29}$

Gajda's removal from the army did not end the "Gajda affair" for several months. In mid-July, the British military attache observed that the controversy surrounding Gajda was mounting so quickly that Gajda would have to act immediately if he were conspiring against the civilian government, but Gajda apparently did little. ${ }^{30}$ An announcement, immediately following his ouster, that Gajda had given a Soviet intelligence agent "secret" French documents while a student at the Ecole de Guerre ${ }^{31}$ aggravated the situation. Gajda himself began to speak out against his detractors in public, and the debate about him raged on. In early September, in an interview with the liberal German paper Prager Tagblatt, even Masaryk entered the fray by denouncing Gajda's activities. ${ }^{32}$ Kramáŕ and Stř́brný defended Gajda, but

25. "Le fascisme tchéchoslovaque et l'armée"; Peroutka, vol. 5, pp. 2820-21, quotes an excerpt of Bechyně's attack on Gajda.

26. Václav Peša, "K otázce počátkủ fašistického hnuti $v$ českých zemích" [On the Question of the Beginning of the Fascist Movement in the Czech Lands], Casopis Matice moravské, 72 (1953): 240.

27. "Le fascisme tchéchoslovaque et l'armée."

28. Conversation of Beneš quoted in Libuše Otáhalová and Milada Cervinková, eds., Dokumenty z historie československé politiky, 1939-1943 [Documents on the History of Czechoslovak Politics, 1939-1943], vol. 1 (hereafter cited as Otáhalová and Cervinková) (Prague, 1966), p. 400.

29. Gajanová, "Ceský fašismus," p. 71; cf. Gajanová's comment in the symposium Fašismus a Evropa [Fascism and Europe], vol. 1 (Prague, 1971), p. 71.

30. Major Oldfield to Sir George Clerk, July 22, 1926, D/19, enclosure in Sir George Clerk to Sir Austin Chamberlain, July 22, 1926, F.O. C 8296/32/12.

31. Einstein to secretary of state, July 13,1926 , USSD 860 f.22/15.

32. Gazette de Prague, September 8, 1926. 
Minister of Defense František Udržal attacked Gajda in the Senate in his speech presenting the 1927 military budget. ${ }^{33}$

By the fall of 1926, Gajda, despite the attention focused on him, no longer possessed a power base within the army (Beneš later admitted that he had great difficulty convincing Czechoslovak army officers of Gajda's misconduct). ${ }^{34}$ The alleged threat of a coup had passed. Gajda's loss of power was illustrated by the appointment of General Alois Podhajský to replace him as acting chief of staff. Podhajský, a former Austro-Hungarian officer, served in the post from September 1 until mid-October, when Syrový could return to his post after the formation of a new cabinet under Svehla. Syrový disliked Podhajský, who was popular among former Austro-Hungarian officers within the army, but Podhajský was one of the most capable officers available to take over the chief of staff's duties.

Despite sympathy for Gajda among the Russian legionaries, Beneš was able to press his case against Gajda, and no high-ranking legionaries openly championed Gajda's cause. In December, a military tribunal convicted Gajda of having had contact with the Soviet government in 1920; he was given the surprisingly light sentence of retirement from the army and the loss of 25 percent of his pension.

Undoubtedly the Gajda affair, which was to drag on until 1928, possessed numerous facets not apparent at first glance. One might imagine, from the initial accusation regarding the French "secret" documents, that Gajda had been removed through the urgings of the French legation or of General Faucher because of Gajda's alleged misconduct in France. However, the records of the French Foreign Ministry show that the French were as mystified as anyone else by the progress of the Gajda affair. General Faucher reported to Paris that Gajda could not have had access to any "secret" documents in France, as students were obviously never given any privileged information. ${ }^{35}$ Gajda was eventually accused of having given the Soviet agent French war manuals. But, as one wit remarked, these could have been procured from practically any bouquiniste along the Seine. If Gajda had been under the jurisdiction of the French government, he could have been arrested under the provisions of the French espionage law of 1888; but the French did not fear that Gajda had done any particular harm to their security. ${ }^{36}$

Another curious aspect of the affair was Gajda's alleged tie to the Soviet Union in 1920. Faucher and the French minister to Prague, M. Couget, were puzzled by the alacrity with which the normally taciturn Soviet trade representative in Prague, Vladimir Antonov-Ovseenko, asserted to other diplomats

33. Einstein to secretary of state, November 2, 1936, USSD 860f.22/15.

34. Otáhalová and Cervinková, vol. 1, p. 400.

35. M. Roux à M. Briand, le 13 juillet 1927 , no. 12, MAE, T-9.

36. Note de M. Corbin, le 12 janvier 1927, ibid. 
that Gajda had indeed been in touch with the Soviets in 1920.37 As Gajda was virulently anti-Communist and pro-Fascist, the Soviets understandably disliked him, but the Soviet role in the affair appeared enigmatic to American, British, and French diplomats. The French speculated that Beneš and Antonov-Ovseenko may have instigated the proceedings against Gajda, and highlevel Soviet interest in the affair was demonstrated by an attack on Gajda in Pravda on January $11,1927 .^{38}$ The Communists also joined the Socialists in attacking Gajda in the press and in parliament. ${ }^{39}$ While it is not known whether Antonov-Ovseenko provided Beneš with evidence against Gajda, Gajda's alleged contacts with the Soviet government undoubtedly explain why the Gajda affair has never been thoroughly discussed in the writings of contemporary Czechoslovak scholars. The Communist effort to discredit Gajda may be understood in relation to the attitude of the Soviet government in 1926, for the Soviets were seeking the diplomatic recognition of Czechoslovakia and were attempting to weaken anti-Soviet groups in Czechoslovak political life. ${ }^{40}$

The attempt of Masaryk and Beneš to discredit Gajda encountered difficulties in 1927 when Gajda used a civil court.to sue the two main witnesses against him for libel. The charges against Gajda were not supported by documentary evidence but by the personal testimony of an old foe, Major Jaroslav Kratochvil (a Social Democrat and former Russian legionary who had opposed the Allied intervention in Siberia), ${ }^{41}$ and two other witnesses of dubious personal integrity, who held personal grudges against Gajda. Much to the embarrassment of the Hrad, the civil court upheld Gajda's suit in a decision announced in March 1927.42 There was no longer any danger that Gajda might recover his military post, but he threatened to become a powerful ally of right-wing forces in Czechoslovak politics.

This setback did not deter the Hrad from producing further evidence to discredit Gajda and to bring him to trial a second time, as was permitted under Czechoslovak law. In 1926, Masaryk and Beneš had privately claimed

37. Czechoslovakia and the USSR had no formal diplomatic relations in 1926, but the two countries had exchanged low-level diplomatic personnel since 1920, when trade missions were established in Prague and Moscow. On the French reaction to Soviet statements, see M. Couget à M. Briand, le 13 juillet 1926, no. 173, MAE, T-9.

38. The Soviets especially resented Gajda for his conduct in Siberia during World War I; a concise Soviet view of Gajda may be found in the Bol'shaia sovetskaia entsiklopediia [The Great Sovict Encyclopedia], vol. 14 (Moscow, 1929), p. 306.

39. Peša, "K otázce počatků fašistického hnutí v českých zemích," p. 236.

40. See Ihor Andrianovych Peters, Chekhoslovatsko-sovetskie otnosheniia, 1918-1934 [Czechoslovak-Soviet Relations, 1918-1934] (Kiev, 1965), p. 222.

41. See Jaroslav Kratochvil, Cesta revoluce [The Path of Revolution] (Prague, 1928), pp. $430-38$.

42. M. de Seguin à M. Briand, le 8 novembre 1927, MAE, T-9; Einstein to secretary of state, March 8, 1927, USSD 860f.22/22. 
to possess additional proof that Gajda had been in contact with the Soviet government in 1920. This "proof" was made public in 1927 by Beneš in a further attempt to embarrass Gajda. On October 27, 1927, members of the Czechoslovak Senate were read the texts of telegrams allegedly sent from the Soviet commissar for foreign affairs, G. V. Chicherin, to the head of the Soviet Trade Delegation in Prague, Gillerson (Czech spelling: Hillerson) in 1920. A telegram of October 27, 1920 from Chicherin to Gillerson read as follows:

To invite Gajda in our name to come here is inopportune. Nevertheless, if he writes us and asks to come here we cannot object; the authorization is assured in advance. It would be interesting to know beforehand what offers he will make us; we have nothing to offer him and we await what he will say to us. Arrange it so that the initiative comes from him and not from us. ${ }^{43}$

Did these telegrams prove Gajda's contacts with the Soviet government? President Masaryk described the curious background of the Czechoslovak possession of the telegrams to the British minister to Prague, Sir George Clerk. Under the agreement establishing the Soviet Trade Delegation in Prague, all telegrams sent from Moscow to the Trade Delegation were sent directly to the Czechoslovak Foreign Ministry. In 1920, the Czechoslovak government lacked the facilities to decode the telegrams, and they were only decoded after being sent to Switzerland in 1921. According to Masaryk, when the telegrams were decoded, several were found to mention Gajda. ${ }^{44}$

The question then arises, if Gajda had been implicated in contacts with the Soviet government when the telegrams were decoded, why did the Czechoslovak government take no action against him in 1921? Masaryk told Sir George Clerk that the Czechoslovak government did not want to reveal that the telegrams had been deciphered. Masaryk thus justified Beneš's having waited five years before going to the minister of national defense with the information. ${ }^{45}$ One can hardly believe, however, that the Czechoslovak government could not have investigated Gajda without informing the Soviet government, nor can one imagine that Masaryk would have tolerated one of his key officers being in contact with an enemy nation. It is also somewhat doubtful that the Soviet government would have transmitted telegrams implicating Gajda to the Foreign Ministry, when the Soviets could easily have used other means of communication to protect their confidential contacts with Gajda. The Catholic newspaper Lidové listy (The People's Journal) noted

43. Einstein to secretary of state, February 16, 1928, USSD 860f.22/26; Gittings (Charge a.i.) to secretary of state, November 5, 1927, USSD 860f.22/24.

44. Sir George Clerk to Sir Austin Chamberlain, October 6, 1926, no. 288, F.O. C $10842 / 83 / 12$.

45. Ibid. 
that the telegrams probably could not be used in a Czechoslovak court against Gajda because they involved third parties. ${ }^{46}$ Indeed, the telegrams were never produced as evidence in a civil court. Masaryk told Sir George Clerk that he was personally convinced of Gajda's guilt, but he complained that Soviet officials refused to give evidence against Gajda in court. ${ }^{47}$ Soviet officials, however, could hardly have become involved in a Czechoslovak court case against Gajda regarding intelligence matters.

Gajda was tried anew in a special military court of appeals and, in February 1928, he was found guilty of six charges: (1) negotiating with the Soviet government at a time when the Czechoslovak government was on unfriendly terms with Moscow, (2) giving two books of information from the Ecole de Guerre to a Russian intelligence agent while a student in France, (3) publicly criticizing his leave of absence, (4) cooperating with the Fascist movement in Prague, (5) plotting the overthrow of the Czechoslovak government with General Josef Snejdárek, ${ }^{48}$ and (6) giving out false statements about his military training and service to newspapers in order to influence public opinion. ${ }^{49}$ In spite of the seriousness of these charges, Gajda's punishment was only a reaffirmation of his retirement from the army and the loss of one-quarter of his pension.

A careful examination of the charges may reveal why Gajda was not punished more severely. At first glance, the evidence supporting the charges seems substantial. There can be no doubt that Gajda's political activities provided ample cause for his removal from the army. Moreover, he cooperated with Fascist groups and publicly criticized his leave of absence. However, it is noteworthy that Gajda, who had meddled in politics since 1920 , had never previously been disciplined for his political activities. The three charges relating to conduct unbecoming to an officer $(3,4$, and 6$)$ were supplemented by three additional charges which were used to discredit Gajda in the eyes of the Czechoslovak public. The military court of appeals was composed of two hand-picked legionaries and one former Austro-Hungarian officer who undoubtedly were willing to go along with the views of government officials eager to discredit Gajda. ${ }^{50}$ Gajda had won a civil suit against the two witnesses

46. Gittings to secretary of state, November 5, 1927, USSD 860f.22/24.

47. Sir George Clerk to Sir Austin Chamberlain, October 6, 1926, no. 288, F.O. C $10842 / 83 / 12$.

48. Snejdárek was a Czech who joined the French Foreign Legion before the First World War. When the Czechoslovak legion in France was formed, he was transferred to it; he then returned to Czechoslovakia as a member of the French military mission. A close associate of Mittelhauser, he disliked Russian legionaries such as Gajda and Syrový, whom he regarded as unprofessional soldiers and amateurs.

49. Le Général Faucher à M. le Ministre de France à Prague, le 11 février 1928, MAE, T-9.

50. Ibid. 
who charged him with having stolen two books of information from the Ecole de Guerre, but the military court, which was not open to the public and which was governed by rules of evidence different from those of a civil court, upheld the witnesses' testimony.

Although popular speculation had focused on Gajda's alleged plan for a coup, the only charge relating to a military conspiracy was that he had advocated the overthrow of the government to General Snejdárek. Gajda and Snejdárek were not on close terms, and there is no clear indication of why Gajda would have chosen Šnejdarek as a confidant. Gajda claimed that the meeting with Šnejdárek, at which the "plotting" was discussed, was arranged by Beneš. Beneš, of course, denied Gajda's assertion. ${ }^{51}$ The Czech historian Alena Gajanová accepts Beneš's version of the incident, but, in view of Beneš's boasting in 1943 (Beneš claimed principal credit for discrediting Gajda and for covering up Masaryk's attempted bribe ${ }^{52}$ ) about his role in the removal of Gajda, further evidence would be necessary to demonstrate the veracity of either Beneš or Gajda. In 1928, Beneš also accused Gajda of cooperating with former Minister of National Defense Střibrny, ${ }^{53}$ but this accusation was politically motivated and casts further doubt on the veracity of Beneš's public statements. Strribrný was never arrested with Gajda, and if, in 1926, either Beneš or Masaryk, or Faucher, had had any suspicion that Gajda and Stríbrný were plotting, Gajda would certainly not have been given temporary control of the General Staff.

Only two historians have attempted to document Gajda's alleged military conspiracy. The first of these is Juraj Kramer, who has described contacts between Gajda and Slovak dissidents led by Vojtech Tuka. In Iredenta a separatismus $v$ slovenskej politike (Iredenta and Separatism in Slovak Politics), Kramer cites Hungarian diplomatic reports stating that Gajda met three times with Tuka in the first half of 1926, and that Gajda, on June 27, came to an agreement with Tuka to carry out a Putsch before the presidential elections of $1927 .{ }^{54}$ Kramer's evidence, however, does not justify the conclusion that Gajda was plotting a coup during the Sokol festival in 1926. If we ignore the possibility that the information in the diplomatic reports was only partially accurate, we would still be forced to conclude that Gajda's agreements with Tuka were rather tentative. Moreover, Tuka's own political

51. Gajanová, Dvoji tvár̆, p. 195.

52. Otáhalová and Cervinková, vol. 1, pp. 400-401.

53. Klepetář, pp. 237-38.

54. Juraj Kramer, Iredenta a separatismus $v$ slovenskej politike [Iredenta and Separatism in Slovak Politics] (Bratislava, 1957), pp. 132-33. See also Kramer, Slovenské autonomistické hnutie v rokoch 1918-1929 [The Slovak Autonomist Movement in the Years 1918-1929] (Bratislava, 1962), pp. 343-47. 
confession, dated April 22, $1935,{ }^{55}$ indicates that Tuka's contacts with Gajda were informal:

Revolutionary feeling flared up again in 1926. There were wild rumors: "Leftist parties prepare a coup," "Czech Fascists prepare a coup." I explored both eventualities. I negotiated with the Czech Fascists about common action, of course, on condition that Slovakia would be granted autonomy by the new regime. I negotiated also with the Communists about the possibility of common action. It did not matter to me with whom I worked. ${ }^{56}$

In 1926, although both left- and right-wing movements in Czechoslovakia were extremely vocal, the more extreme Fascist groups were relatively weak, representing a threat to the power of Masaryk more through their connections with important politicians like Kramár and Strribrný than through their own intrinsic strength.

Gajda's alleged plotting has also been described by Václav Peša. In an article appearing in 1953, Peša quotes an informant who indicated that the Fascists and Gajda wanted to carry out a coup in October 1926. ${ }^{57}$ The informant's information is found in the Brno archives, but, considering the rampant rumors in 1926, it cannot be taken seriously without additional evidence. Gajda was, of course, partially responsible for inciting the Fascist hopes, but accusing him of plotting a military coup would be too harsh a judgment in the light of available evidence. Furthermore, it is surprising that so little evidence concerning "coup plotting" was uncovered, in view of the fact that Gajda had many personal enemies among former AustroHungarian officers and even among the legionaries. Even though contemporaries felt that Gajda's friendship with Syrovy and certain other legionaries prevented a stronger sentence, ${ }^{58}$ the lack of evidence against him was certainly a factor in his lenient treatment. ${ }^{58}$ The government clearly did not want to create a martyr for the Fascists.

55. Tuka was arrested, tried, and convicted in 1929 on charges of treason and espionage. As a condition of his release from prison, Minister of Justice Ivan Dérer had Tuka write a confession, which was then read into the Czechoslovak parliamentary debates. Dérer felt an almost pathological hatred for Tuka, and he published all the evidence of Tuka's unlawful activity he could find.

56. Quoted in Ivan Dérer, Slovenský vývoj a lud'ácká arada [Slovak Development and the People's Party's Betrayal] (Prague, 1946), pp. 61-62. Also see Karol Sidor, Slovenská politika na pôde pražského snemu [Slovak Politics in the Prague Parliament], vol. 2 (Bratislava, 1943), p. 211. Gajda was not an issue at Tuka's trial. See, for example, J. Smida, The Tuka Trial (Bratislava, 1930).

57. Peša, " $\mathrm{K}$ otázce počatků fašistického hnutí v českých zemích," pp. 247-48. Gajanová, Dvoji tvár̆, pp. 42-44, cites the mutually contradictory evidence of Kramer and Peša but fails to account for the differences between the two.

58. “Czechoslovakia, Annual Report, 1928," F.O. C 2322/2322/12.

59. The lack of clear evidence was illustrated by Benešs own admission that he had difficulty discrediting Gajda. See Otáhalová and Cervinková, vol. 1, pp. 400-401. 
After his conviction, Gajda remained active in Czechoslovak politics, though he was unable to build a strong power base. He was elected a deputy to Parliament in 1929 and remained active in the NOF. Following his election, Gajda became involved in several other political scandals. In 1931, he was implicated in a political intrigue, stripped of his parliamentary immunity, and forced to give up his pension. In 1934, several Gajda supporters, including his nephew Duchoslav Geidl, were arrested during a raid on the barracks of the Forty-third Infantry Regiment in Brno. Gajda was found guilty of having had prior knowledge of the raid, though it could not be proved that he was directly involved. ${ }^{60}$ Thereafter Gajda remained a vocal but relatively powerless critic of the Czechoslovak regime.

While Gajda never achieved success in carrying out his political ambitions, his activities prompted many moderate Czech politicians to try to remove the army from politics. In the fall of 1926, the Cerny cabinet sponsored a bill eliminating the voting franchise from the officer corps and gendarmerie. In the early 1920s, voting in the army had been permitted as a concession to socialism and populism, but voting encouraged officers to become involved in politics. The Russian legionaries, in particular, became a vocal political group, which was represented in Parliament by several legionary deputies holding specially-reserved mandates. Many Czech political figures like Cerný and Svehla were happy to correct former abuses by sponsoring a new franchise bill which eventually became Law number 56 of April 8, 1927.91 Most legionaries opposed the bill, while former Austro-Hungarian officers, who were generally more apolitical, supported it with enthusiasm. ${ }^{62}$ Even the semiofficial Central European Observer admitted that the results of the law were beneficial to discipline in the barracks, which had previously been racked by political disputes during election campaigns. ${ }^{63}$

A second blow to legionary power followed in late 1926 and 1927, when Prime Minister Švehla and his fellow-Agrarian Udržal arranged for the appointment of Podhajský, Gajda's successor as acting chief of staff, to the post of inspector-general of the army. The latter post had been vacant since 1924, when the previous inspector-general, the poet Josef Svatopluk Machar, had been forced to retire in a scandal. Supporters of the former AustroHungarian officers were eager to have Podhajsky appointed to lessen the legionary influence in the army, but Masaryk resented Czech officers who had remained loyal to the Habsburgs. He told Udržal that he would not

60. See Pasák, pp. 120-25.

61. Sbirka zákonù a nařizení státu českoslovenkého [Sammlung der Gesetze und Verordnungen des čechoslovakischen Staates]. The law was supplemented by Decree 67 of May 28, 1927.

62. Sir George Clerk to Sir Austin Chamberlain, September 15, 1926, no. 272, F.O. C $10228 / 374 / 12$.

63. Central European Observer, December 9, 1927. 
countersign Udržal's administrative order appointing Podhajský as was required by the Constitution. When Masaryk went on a trip to the Near East in 1927, however, Udržal signed the order and put Masaryk in the embarrassing position of being unable to block the appointment. On his return, Masaryk had to assent to the signing of the order to avoid losing face. ${ }^{64}$ The appointment of Podhajsky, one of the most able officers in the army, added an additional element of stability to the officer corps. Acting as a counterweight to the power of the legionaries, his appointment decreased the possibility of a second "Gajda affair."

The Gajda affair thus had complex consequences affecting many areas of Czechoslovak military and civilian life. The affair demonstrated that, although the civilian government could be shaken by political crises, civilians were still firmly in control. As far as the army was concerned, the removal of Gajda put an end to the worst abuses of the legionary movement. The appointment of Podhajský as acting chief of staff and, in 1927, as inspectorgeneral showed that, in the final analysis, many Czechoslovak politicians preferred experienced Austro-Hungarian officers to unreliable officers like Gajda, whose activities had threatened the political neutrality of the army. Czechoslovakia was fortunate, nonetheless, for most prominent legionaries, like Syrový, lacked strong political ambitions and were content to let the French military mission guide the army's development. Fascism never became a dominant force among the legionaries. The French military mission, while benefiting from Gajda's removal, was a spectator in the events of 1926 and 1927. General Faucher told the British military attache in 1926 that the French military mission found the whole matter "tiresome." The British military attaché commented: "The whole situation would be inconceivable in one of the more civilized western armies. For myself, I do not pretend to understand it." 66

Although several historians have claimed that Radola Gajda intended to carry out a coup in 1926, the Gajda affair should be interpreted as a factional dispute accompanying the intrigues of Czechoslovak political parties in 1926 rather than as a full-fledged conspiracy to overthrow the government by military force. Fascist agitation in Czechoslovakia coupled with the Pilsudski coup in Poland induced many Czechs and Germans to fear that Gajda represented a serious threat to civilian government, but Gajda never had a role within the Czechoslovak Army as powerful as that of Pilsudski in Poland.

64. Le Général Faucher à M. le Ministre de la Guerre, no. 647, enclosure in Le Ministre de France à Prague à M. le Ministre des Affaires-Etrangères, le 10 mai 1927, no. 205; Le Général Faucher à $M$. le Ministre de la Guerre, no. 663/cab., MAE, T-9. $157 / 2$.

65. On Podhajský, see Eglin to War Department, August 23, 1926, USWD 2494

66. Major Oldfield to Sir George Clerk, July 22, 1926, no. D/19, enclosure in Sir George Clerk to Sir Austin Chamberlain, July 22, 1926, no. 226, F.O. C 8296/83/12. 
When Gajda was removed in July 1926, he had not consolidated his power to a point where he could have used force-if indeed he contemplated the use of force. Beneš and Masaryk produced a wide range of accusations against Gajda, linking him both with the Soviet Union and with the Fascists in order to destroy his ties to Kramár and Stríbrný. Though victorious in their endeavors, Masaryk and Beneš employed tactics similar to those of their opponents; and Benešs own admission-if true-that Masaryk tried to bribe Gajda demonstrates how the political debate of 1926 was conducted. The issue of Gajda's inadequate abilities as a military officer was lost in the melee of accusations and counteraccusations.

As a result of the political infighting, the Hrad emerged victorious over Kramář and Stříbrný and their tacit legionary ally, Gajda. ${ }^{67}$ Kramár̆, however, soon realized that Gajda was thoroughly discredited. He abandoned Gajda and reached a modus vivendi with Masaryk and Beneš. ${ }^{68}$ Stríbrný, on the other hand, continued his association with Gajda, and emerged from the affair with weakened public support. By keeping Benes in the Ministry of Foreign Affairs, Masaryk ensured the continuity of his personal influence in the government, and also maintained Benešs influence in foreign affairs. A few aspects of the Gajda affair, in particular the issue of Gajda's alleged contacts with the Soviet government, may remain enigmatic for some time to come, but it is clear that Gajda's fall contributed to the stability of Czechoslovak political life by affirming Masaryk's power.

67. Mr. Keeling to Sir Austin Chamberlain, January 19, 1938, no. 13, F.O. C 442/ $365 / 12$.

68. See František Nečásek et al., eds., Dokumenty o protilidové a protinárodni politice T. G. Masaryka [Documents on the Anti-People and Anti-Nation Politics of T. G. Masaryk] (Prague, 1953), no. 49. 